\title{
Bernadetta Darska
}

Uniwersytet Warmińsko-Mazurski w Olsztynie

\section{PRETEKSTEM JAREMIANKA \\ O biografii, reportażu biograficznym i nie tylko}

On the Pretext of Jaremianka: About Biography, Biographical Reportage, and More 


\begin{abstract}
Abstrakt: Artykuł stanowi próbę krytycznego namysłu nad publikacją Agnieszki Daukszy Jaremianka. Biografia w kontekście współczesnych tendencji w biografistyce. Najważniejsze poruszane wątki to: obecność autora biografii w tekście, osobisty charakter refleksji biograficznej, pytanie o granicę między biografią a reportażem biograficznym oraz związki analizowanej pracy z herstorią.
\end{abstract}

Słowa kluczowe: Maria Jarema, biografia, reportaż biograficzny, granice gatunków, herstoria

\begin{abstract}
This article offers a critical reflection on Agnieszka Dauksza's book Jaremian$k a$. Biografia, a biography of the artist Maria Jarema. Situating the publication in the context of contemporary trends in biographical writing, it concentrates on the following topics: the biographer's presence in the text, the personal character of biographical reflection, the question of the border between biography and biographical reportage, and the relationship of the work under discussion with herstory. (Transl. Z. Ziemann)
\end{abstract}

Keywords: Maria Jarema, biography, biographical reportage, genre boundaries, herstory 


\section{gnieszka Dauksza rozpoczyna swoją opowieść o Marii Jaremie od wyznania Ao zapatrzeniu w fotografię:}

Doszło do tego, że przez długie godziny wgapiałam się w portret Jaremy. Czekałam, aż się poruszy. Liczyłam, że wraz z tym ruchem odsłoni się rąbek tajemnicy, zobaczę Marię pod innym kątem. Chociaż drobny gest, mrugnięcie, kosmyk włosów w lewo, lekki półobrót? Prowokowałam ją na różne sposoby, powielając fotografię do bladości. Zaglądałam jej w oczy wprost do pikselowych ziaren, farbowałam włosy, kontrastowałam, studiowałam rysy twarzy, zagnieżdżałam się w porach skóry. Dawałam jej czas, chciałam, żeby dojrzała do tego ruchu. Zerkałam na nią znienacka i patrzyłam w skupieniu, do góry nogami, w negatywie, sepii i przez lupę. Rozpoznawałam w niej inne osoby, inne twarze, obce, znajome, pokrewne. Maria niewzruszenie pozostawała sobą ${ }^{1}$.

Sobą miała pozostać, ale wzrok autorki, choć nie będzie przecież patrzeniem prosto w oczy na żywo, lecz jedynie spoglądaniem zapośredniczonym, wydobywa wieloznaczności, które okażą się istotne. Jaremianka zapamiętana przez ważne postaci świata sztuki i kultury naznaczy je swoją obecnością. Ludzie ci faktycznie więc odbiją się w jej oczach. Dauksza wpatrująca się w zdjęcie malarki metaforycznie ujmuje proces rodzenia się więzi między autorką a bohaterką tekstu, więzi w sensie dosłownym niemożliwej, w sensie intelektualnym jednak silnej i, co widać w opowieści, trwałej. Nie bez powodu używam słowa „zapatrzenie”. Stan, który rekonstruuje autorka, stanowi połączenie fascynacji z uważnością, jakby $\mathrm{w}$ parze z obsesyjnym wpatrywaniem się szła wiara w symboliczne nawiązanie kontaktu. Poetyckie, a zarazem bardzo sensualne wprowadzenie wikła czytelnika w specyficzną perspektywę odbioru. To, co w niej najważniejsze, wiąże się ze

\footnotetext{
1 A. Dauksza, Jaremianka. Biografia, Kraków 2019, s. 5.
} 
współdzieleniem osobistego zaangażowania i świadomością uczestnictwa w procesie opowiadania, który polega na wymykaniu się i robieniu uników tam, gdzie można by oczekiwać wyrazistych wyznaczników gatunkowych. Zapatrzenie autorki w bohaterkę nie prowadzi do samolubnego anektowania intelektualnej i emocjonalnej więzi, jaka rodzi się stopniowo wraz z poznawaniem kolejnych faktów na temat życia Marii Jaremy. To raczej gest wspólnotowy, rodzaj zaproszenia do dzielenia pasji, świadomość możliwego współodczuwania i forma budowania sieci powiązań, w których znaleźć się może i portretowana artystka, i biografka jej losów, i czytelnicy. Dzięki temu dla czytelników Jaremianka stanie się kimś żywym, realnie istniejącym i nadal oddziałującym siłą swojej osobowości.

Dauksza nie poprzestanie na zasygnalizowaniu napięcia między tym, co widzialne, i tym, co po malarce pozostało. Będzie do tej perspektywy wracała. Można nawet powiedzieć, że skupienie na zdjęciach stanie się, tak to określmy, praktyką podwójnego potwierdzania istnienia. Wpatrywanie się w twarz Jaremianki da pewne podstawy do wskazywania lub zaledwie sugerowania momentów tożsamościowo zwrotnych, gdy właśnie w oczach, w grymasie ust, w pochyleniu głowy lub w postawie ciała można próbować zauważyć to, czego potwierdzenia nie uda się znaleźć w dokumentach. Dauksza potrafi interpretować i fabularnie rozbudować tak uchwycone fragmenty życia. Raptem okazuje się, że wierzymy w to, co prawdopodobnie wtedy się wydarzyło, że ufamy przypuszczeniom autorki, a umiejętne rozmieszczenie zdjęć w tekście dodatkowo wzmacnia sugestywność ich oddziaływania. Odwoływanie się do fotografii wzbogaca relacjonowaną biografię. Bez nich nie dałoby się dostrzec wszystkiego, o czym Dauksza opowiada. Nie zawsze zdjęcia tak dobrze rezonują $\mathrm{z}$ historią, ale w tym wypadku można mówić o zaskakującej wręcz spójności. W efekcie czytelnik nie tylko czyta o Marii Jaremie, lecz także ją widzi. Zostaje włączony w ustanowioną na początku relację między bohaterką a autorką, a lektura biografii nabiera osobistego wymiaru. Dlatego czytelnik, podobnie jak Dauksza, wpatruje się usilnie, chce zobaczyć więcej, zaczyna wierzyć, że ze zdjęcia da się wyczytać coś, co przyniesie pełniejszą wiedzę od tej, która wynika z tekstu.

Artystka nie została, rzecz jasna, potraktowana zdawkowo. Byłby to literacki grzech nie do wybaczenia, ale też byłoby to niemożliwe. Tak barwnego życia nie da się nie opowiedzieć atrakcyjnie. Niezależnie od projekcji tego, co mogłoby się potencjalnie zdarzyć, Dauksza nie tylko oferuje czytelnikom znakomitą biografię malarki, ale także buduje wokół niej tyle istotnych kontekstów, że Jaremianka, pozostając cały czas na głównym planie, staje się pretekstem dla wielu innych bezpośrednio lub pośrednio sygnalizowanych w publikacji wątków. Marię Jaremę można zatem traktować jako centrum opowieści, na którym skupia się uwaga czytelników i autorki, a zarazem punkt odniesienia, uruchamiający szereg istotnych skojarzeń, dzięki którym biografia indywidualna 
zamienia się, zabrzmi to chyba nazbyt patetycznie, w biografię świata Jaremianki - rzeczywistości artystki i tych, którzy z nią współegzystowali.

W tym najbardziej oczywistym rozumieniu Jaremianka Daukszy wydaje się ważnym pretekstem do dyskusji na temat ograniczeń gatunkowych, czystości gatunku i możliwości poszerzania gatunkowych definicji. Na okładce książki pod tytułem znajdziemy informację, że mamy do czynienia z biografią. Tymczasem na stronie tytułowej jako podtytuł nie figuruje już przyporządkowanie gatunkowe, lecz pytanie: „Gdzie jest Maria?”. Zderzenie tych dwóch informacjijednej mocno zakorzenionej w literaturoznawczych odniesieniach i powiązanej z konkretem, drugiej odnoszącej się do wątpliwości i tego, co niepewne - bardzo dobrze zapowiada wszystko, co znajdziemy na kartach książki. Jaremianka będzie więc odsłaniała się przed nami, nasza wiedza zostanie wzbogacona, ale jednocześnie ze strony na stronę narastać w nas będzie poczucie, że bohaterka książki cały czas się nam wymyka, a jej poznanie jest właściwie niemożliwe. Przekonali się o tym jej partnerzy życiowi - Henryk Wiciński, Gabriel Gustaw Gottlieb i Kornel Filipowicz. Przekonujemy się pośrednio i my, gdy czytamy o jej potrzebie wolności i niezależności, gdy obserwujemy jej pasję tworzenia, gdy odkrywamy bezkompromisowość w uprawianiu, przeżywaniu i komentowaniu sztuki, gdy widzimy wreszcie jej rozpaczliwe, ale też pełne godności i świadomości odchodzenia, czepianie się życia wtedy, gdy koniec jest blisko.

Trudno nie zgodzić się z okładkową deklaracją Daukszy, że pisze biografię, ale i trudno z tym nie polemizować. W sprzeczności z tego rodzaju przyporządkowaniem pozostaje nie tylko przyjęta na początku i pięknie literacko rozpisana osobista perspektywa oglądu. Do dyskusji nad gatunkiem skłania również uruchamiana w tekście refleksja nad pamięcią tkwiącą w przedmiotach, które po Jaremiance pozostały, nad obecnością śladów biografii malarki w twórczości Kornela Filipowicza czy Tadeusza Różewicza. Genologiczne pytania prowokują ponadto $\mathrm{z}$ jednej strony wnikliwe analizy fotografii, $\mathrm{z}$ drugiej zaś dzielenie się własnymi emocjami i wątpliwościami oraz budowanie napięcia, dzięki któremu opisywane relacje ożywają. W trybie formalnym trzeba by też wspomnieć o braku przypisów przy jednoczesnym pieczołowitym odnotowaniu wielu pozycji w bibliografii i umieszczeniu w książce indeksu osobowego.

Może więc Dauksza proponuje czytelnikom erudycyjny i niezwykły w swojej literackości reportaż biograficzny? Nie byłoby w tym nic dziwnego, zwłaszcza że cienka granica między tymi gatunkami jest często nie do uchwycenia. Diana Poskuta-Włodek pisała o interesującej nas książce:

Wydana przez Znak biografia Jaremianki oscyluje na pograniczu reportażu i eseju, jest sprawnie napisaną, udaną próbą popularyzacji, rodzajem „impresyjnej faktografii”, książką, którą z niemałą czytelniczą przyjemnością pochłania się jednym tchem. W tym sensie 
ta praca pozostaje w nurcie bodaj najchętniej publikowanych ostatnio przez wydawnictwa, poczytnych biografii ${ }^{2}$.

Zdarza się współcześnie bardzo często, że publikacje wymiennie przyporządkowywane są raz do biografii, innym razem do reportaży biograficznych. Dzieje się tak również w kontekście nagród literackich. Książka Gareth Jones. Człowiek, który widział za dużo Mirosława Wlekłego została na przykład zgłoszona do Nagrody im. Ryszarda Kapuścińskiego za najlepszy reportaż, a jednocześnie jest finalistką Górnośląskiej Nagrody Literackiej Juliusz doceniającej biografie. Sendlerowa. W ukryciu Anny Bikont to publikacja, która ukazała się w serii „Biografie” Wydawnictwa Czarne, natomiast wyróżniono ją Nagrodą im. Ryszarda Kapuścińskiego jako najlepszy reportaż. Takie przykłady można by mnożyć. Dzikowska Romana Warszewskiego to książka reklamowana na okładce jako ,pierwsza biografia legendarnej podróżniczki”, chociaż bliżej jej do reportażu biograficznego. Najbardziej bodaj rozpoznawalnym przykładem swobodnego podejścia do obu gatunków jest twórczość Magdaleny Grzebałkowskiej. Kojarzona ze sztuką reportażu autorka, zajmując się biografiami księdza Jana Twardowskiego, Zdzisława i Tomasza Beksińskich czy Krzysztofa Komedy, swobodnie łączy oba sposoby narracji. Biegun biograficzny tego rodzaju pisarstwa jest mocniej związany z dokumentami i lekturami kontekstowymi, biegun reportażowy oznacza nastawienie na kontakt z żywym człowiekiem, ujawnianie reguł rządzących pracą reportera, a także świadomość aktualności i uniwersalności tego, co historyczne. Choć intuicyjnie często jesteśmy w stanie wskazać różnice, to rozgraniczenie bywa niemożliwe. Czy jednak jest potrzebne?

I tak, i nie. Tak, ponieważ odejście od gatunku bywa sygnałem autorskiej bezradności. Trwający boom na reportaż wiele takich sytuacji odsłania. Nie inaczej jest z coraz większą popularnością biografii. Dzielenie się refleksją na temat braku możliwości dotarcia do materiałów, mówienie o własnym zagubieniu, zwierzanie się z samotności $\mathrm{w}$ trakcie pracy nad tekstem czy próby poradzenia sobie $\mathrm{z}$ odmową rozmowy lub niemożnością jej przeprowadzenia to wyzwania czyhające i na biografów, i na reporterów. Taki tryb pracy reporterskiej i biograficznej widać chociażby w Pani Stefie Magdaleny Kicińskiej, książce poświęconej współpracującej z Januszem Korczakiem Stefanii Wilczyńskiej. Bywa również tak, że reporter, chcąc opowiedzieć o jakimś problemie lub doświadczeniu, posiłkuje się autobiografią, czyniąc z własnego życia metaforę czegoś większego. Przykładem takich działań może być chociażby reportaż Roberta Rienta Świadek, gdzie osobiste przeżycia autora stanowią ważne uzupełnienie historii przynależności do Świadków Jehowy. Z kolei Maciej Zaremba Bielawski w Domu z dwiema wieżami mierzy się z historią własnej rodziny, dzięki której snuje również opowieść

2 D. Poskuta-Włodek, Jaremianka. Kompozycja, „Didaskalia” nr 156 (2020), https://didaskalia.pl/pl/artykul/jaremianka-kompozycja [dostęp: 15 IX 2020]. 
o charakterze uniwersalnym, poruszając takie zagadnienia, jak tożsamość, wykluczenie, napiętnowanie, kwestia zależności czy antysemityzm. Publikacja ta, choć reportażem nie jest, została wyróżniona Nagrodą im. Ryszarda Kapuścińskiego. Praktyka ujawniania własnej obecności i wprowadzania w tekst odautorskiego, często osobistego komentarza coraz częściej staje się strategią formalnie przemyślaną i współtworzącą kompozycyjną spójność.

Agnieszka Dauksza nie jest więc w tej praktyce wyjątkiem, choć na pewno jej realizacja zalicza się do wyjątkowych. Aleksander Kaczorowski, wypowiadając się jako juror Górnośląskiej Nagrody Literackiej Juliusz, zauważa:

Dauksza rekonstruuje jej [Jaremianki] osobowość z nielicznych zachowanych świadectw i dokumentów; z niewiarygodną empatią, niczym archeolog w krainie umarłych, wydobywa na światło dzienne uczucia i pragnienia, dramaty i euforie nie żyjącej od dawna bohaterki. Dojrzewa razem z nią. W ten sposób niepostrzeżenie dla czytelnika - i może dla samej autorki - biografia Jaremy całkiem naturalnie, bez jednej fałszywej nuty, bez choćby jednego kiksu, staje się także biografią Daukszy. Na kartach książki bohaterka naprawdę ożywa i staje się przewodniczką biografki po świecie sztuki - i po sztuce życia. Ta niesamowita symbioza bohaterki i autorki książki, to dokonujące się na oczach czytelnika porozumienie duchowe dwóch kobiet, które za życia nigdy się nie spotkały, lecz potrzebowały siebie nawzajem, by w niepowtarzalny sposób zaistnieć w świecie literatury, jest czymś niesamowitym³ ${ }^{3}$.

Ta bardzo ciekawa podpowiedź interpretacyjna sytuuje biografię w zupełnie innych rejonach, niż zdążyliśmy się do tego przyzwyczaić. Spotkanie z bohaterem lub bohaterką dzieła będzie w tym odczytaniu już nie tylko doświadczeniem formacyjnym, intelektualnym, twórczym, ale również głęboko intymnym, emocjonalnym i psychologicznie niejednoznacznym.

Czy zatem określenia gatunkowe „biografia” lub „reportaż biograficzny” nie zatrzymują nas dzisiaj na poziomie nazbyt powierzchownym, bo tylko informacyjnym? Może statyczność wynikająca $\mathrm{z}$ tych przyporządkowań stanowi niepotrzebne ograniczenie już przy pierwszym zetknięciu się z opisywanym życiorysem. Dauksza nie ukrywa, że właśnie ruch i zmiana są dla niej podstawowym wyznacznikiem w próbie uchwycenia życia Jaremianki:

Chciałabym, by mój czytelnik choć przez chwilę zobaczył Jaremiankę w tym ruchu, w toku przeobrażeń, w którym i ja ją widzę. Sama nie wiedziałam, dlaczego chcę o niej napisać, ale po prostu musiałam to zrobić. Zamierzałam zrozumieć, skąd bierze się „efekt Jaremianki”. Z czego wynika jej hardość, co było dla niej motorem napędzającym. Jakie są sploty łączące to, co cielesne, intymne z tym, co artystyczne. Nie jestem pewna, czy znalazłam odpowiedź. Jaremianka wciąż się wymyka. Nieustannie znajduję nowe materiały archiwalne, które poka-

3 Wypowiedź A. Kaczorowskiego, https://www.nagrodajuliusz.pl/?news=19634 [dostęp: 15 IX 2020]. 
zują mi tę postać w nieco innym świetle. Maria nie żyje od wielu, wielu lat, a nadal pozostaje sprawcza. Mobilizuje do jakiegoś działania, domaga się czegoś. Jej historia jest wciąż aktualna - rzutuje na nasze myślenie o współczesnym społeczeństwie, relacjach kobiet i mężczyzn, strategiach emancypacji, doświadczeniu artystów, ich konfrontacji z mecenatem państwowym oraz polityką kulturową, mechanizmach tworzenia sztuki i procesach jej odbioru ${ }^{4}$.

Poszerzenie definicji tego rodzaju książek o przymiotniki z pewnością dałoby większe pole manewru, jeśli weźmiemy pod uwagę czytelność klasyfikacji. Zarazem jednak mogłoby spowodować pewien zamęt, a przy tym skrzyżować tryb interpretacyjny z porządkującym. Wiele określeń wiązałoby się przecież ze sposobem lektury danego tekstu czy z kompetencjami kulturowymi czytającego. Większe jest jednak ryzyko zafałszowań wynikających z arbitralnego żonglowania kategoriami reportażu biograficznego i biografii podczas prób klasyfikowania dzieła. Jaremianka mogłaby więc okazać się pretekstem nie tylko do dyskusji na temat życia artystycznego Krakowa, emancypacji artystek ${ }^{5}$, pozycji zajmowanej przez awangardę, wreszcie Grupy Krakowskiej czy Teatru Cricot, ale również do wprowadzenia innego modelu nazewnictwa gatunkowego. Wówczas oprócz porządkujących określeń gatunkowych pojawiłoby się więcej dopowiedzeń, uzupełnień, sugestii naprowadzających na styl opowieści, możliwe sposoby odczytania, sposób konstruowania postaci.

W takim ujęciu Jaremianka Agnieszki Daukszy mogłaby faktycznie, jak sugeruje Kaczorowski, być jednocześnie biografią bohaterki i biografią autorki. Opowieść o malarce byłaby w tym kontekście przede wszystkim historią spotkania niemożliwego, bo poza czasem i wspólnym doświadczeniem. Byłaby również podwójną, zawsze w relacji, ale jednak równoległą, herstorią łączącą współczesność z przeszłością. Odczytana i opowiedziana przez Daukszę Jaremianka istniałaby na własnych zasadach, ale prawomocnie funkcjonowałaby również jako część wyobraźni twórczej autorki. Kompozycyjne połączenie opisu świata bohaterki z autorskimi wzruszeniami, wątpliwościami i zadawanymi sobie pytaniami byłoby nie tylko uzasadnione, ale i niezbędne. Dla każdej opowieści biograficznej potencjalnie ważne są przecież nie tylko fakty, które uda się ustalić, ale i osobowość tego, kto te fakty zbiera. Fundamentalne staje się więc nie tylko to, jak się opisuje, ale i kto za opowieścią stoi. Biografia okazuje się wypadkową wiedzy na temat bohatera lub bohaterki oraz osobowości twórcy kreślącego jego lub jej portret.

\footnotetext{
4 Artystka niezawłaszczona. Z Agnieszka Daukszą rozmawia Paulina Małochleb, „Przekrój” [online 23 VI 2019], https://przekroj.pl/kultura/artystka-niezawlaszczona-paulina-malochleb [dostęp: 22 X 2020].

5 Ciekawe byłoby zderzenie biografii Jaremianki z życiorysami innych artystek. Warto w tym kontekście przywołać chociażby następujące publikacje: A. Kuźniak, Stryjeńska. Diabli nadali, Wołowiec 2015; M. Czyńska, Kobro. Skok w przestrzeń, Wołowiec 2015; M. Czyńska, Berezowska. Nagość dla wszystkich, Wołowiec 2018; A. Kuźniak, Boznańska. Non finito, Kraków 2019.
} 
Dauksza, rozpoczynając książkę od pytania „Gdzie jest Maria?”, nie szuka oczywiście jednej, kategorycznie rozpoznającej bohaterkę, odpowiedzi. Zawsze przecież będą kolejne pytania. Symboliczne ożywianie bohaterki odbywa się więc nie tylko przez skupienie się na szczegółach jej życia czy przez przypomnienie jej twórczości i intelektualnej siły odziaływania. Rozgrywa się raczej w autorskim uświadamianiu sobie ciągłego dziania się i zmiany oraz we włączaniu czytelników książki w ten proces przemiany i odkrywania nowego. Magdalena Furmanik-Kowalska stwierdza:

Użyty przez nią [Daukszę] reporterski, wartki język umożliwił opisanie życia Jaremy w bardzo obrazowy sposób. Czytając biografię, czujemy się, jakbyśmy obserwowali artystkę podczas pracy, przeżywali z nią trudy dnia codziennego (zwłaszcza w okresie wojennym), pili kawę z jej przyjaciółmi, przemierzali wody Wisły kajakiem ${ }^{6}$.

Agnieszka Dauksza nie ukrywa, że fotografie, miejsca i przedmioty powiązane z Marią Jaremą odgrywały w jej spotkaniach z bohaterką wielką rolę. Prawdopodobnie dlatego opowieść o Jaremiance ma tak zmysłowy charakter. Kiedy Kornel Filipowicz wraca z obozu, widzi Marię opalającą się, ona zaś dostrzega go wynurzającego się ze słonecznego, oślepiającego światła. Z kolei wieczór, który pozornie jest pełen beztroski, a w gruncie rzeczy przyniesie istotne pytanie o charakterze ostatecznym, związany będzie ze wspomnieniem niepowtarzalnego zapachu Jaremianki zapamiętanego przez Gabrysia Gottlieba i z duszącą wonią papierosowego dymu. Takich zapachów - mocujących scenę w pamięci, drażniących i intensyfikujących doznania - będzie w tej biografii wiele. Dauksza ożywia więc swoją bohaterkę wszystkimi zmysłami. Na początku jest jednak spojrzenie. Wpatrywanie się w twarz Jaremianki rozpoczyna sensualną wędrówkę przez kolejne mikroświadectwa egzystencji. Autorka zapowiada:

Nie porzuciłam Jaremianki. Już po ukazaniu się książki zaczęły wypływać różne zapomniane, zagubione dokumenty. Próbuję przepisać te okropne gryzmoły Jaremiankowe - miała prawie nieczytelne pismo. Jej nigdy niepublikowane pisma feministyczne i społeczne ukażą się drukiem jeszcze tej jesieni?

6 M. Furmanik-Kowalska, Jarema - awangardowa feministka? Obraz artystki $w$ biografii Agnieszki Daukszy, „Kultura Liberalna” 2020 nr 37, https://kulturaliberalna.pl/2020/08/25/magdalenafurmanik-kowalska-recenzja-agnieszka-dauksza-jaremianka/ [dostęp: 22 IX 2020].

Mówili mi, że Jaremianka wszystko przegrała $i$ że nie warto o niej pisać. Z Agniesz$\mathrm{kq}$ Daukszq rozmawia Natalia Szostak, „Gazeta Wyborcza” [online 22 IX 2020], https://wyborcza.pl/7,75517,26321262,mowili-mi-ze-jaremianka-wszystko-przegrala-i-nie-warto-o-niej.html [dostęp: 22 IX 2020]. 
Więź nawiązana z bohaterką biografii okazuje się czymś trwałym. To nie epizod i nie przygoda, która się kończy. Można by powiedzieć, że to rodzaj zobowiązania, którego owocem jest ciągłe mentalne przepisywanie biografii emocjonalnej, biografii intelektualnej, biografii odpowiedzialności za pamięć czyjegoś życia. 